\title{
Studying the Drivers of Consumer Behavioural Engagement With Social Media Brand-Related Content
}

\author{
Reham Shawky Ebrahim, Faculty of Commerce, Tanta University, Egypt
}

iD https://orcid.org/0000-0003-4640-5241

\begin{abstract}
The actual behavioural engagement of consumers with social media brand-related content is measured by three activities: consumption, contribution, and creation. This type of engagement is considered the true practical indicator of the success of brand presence on social media. The study aims to uncover the drivers of consumer behavioural engagement identified by the key characteristics of social media context. Accordingly, quality dimensions and perceived usefulness of the brand hosting media channel are adopted from the IT use and acceptance models. Data is collected using self-administrated questionnaire from a sample of 366 respondents in the UK. Structural Equation Modeling-V.26 was used to analyse the data. The results support the significant role of cognitive absorption in explaining how perceptions of social media quality dimensions are shaped to motivate consumer engagement behaviour. The findings enrich the extant literature of consumer engagement; additionally, several practical insights can be drawn related to the design of social media marketing strategy.
\end{abstract}

\section{KEYWORDS}

Brand-Related Activities, CESBC, Cognitive Absorption, IS Success Model, Social Media, TAM

\section{INTRODUCTION}

Nowadays, the role of social media in building successful brands and leveraging its online marketing activities is growing. Social media engagement is one of the most influential developments in brand management. Especially, with more than half of the world's population, constituting some of 3.48 billion people are active users they spend on average 144 minutes daily, i.e., most of their working and personal time are on social media sites (SMS) (Smith, 2019; Veloutsou \& Guzman, 2017). Consumers are experiencing a high level of engagement with brands on social media; thus, managers are forced to support brand success and secure its presence on social media.

It is expected that companies will raise their investments on social media to reach $\$ 48$ billion in 2021 (Guttmann, 2018). Advancements in technology enabled an interactive engagement platform. Brand managers pursue social media users with brand fan pages on social media to interact, build long-term relationships and loyalty, which are used as a new avenue to gain competitive advantage. For example, in February 2020, Samsung has the highest number of followers (160 million) on its

\section{DOI: 10.4018/IJCRMM.2022010106}

This article published as an Open Accesss article distributed under the terms of the Creative Commons Attribution License (http://creativecommons.org/licenses/by/4.0/) which permits unrestricted use, distribution, and production in any medium provided the author of the original work and original publication source are properly credited. 
Facebook fan page and it is ranked among the top companies in the world in terms of market value (Clement, 2020; Statista Research Department, 2020). Moreover, Coca-Cola is one of the most recognisable brands on social media in 2020 with 107 million followers (Clement, 2020), ninety percent of them or even more are interacting with the brand posts on Facebook. The engagement of social media users is expressed by sharing, creating and reviewing brands which contribute much to the successfulness of the company's social media campaign, e.g., \#BTS_cocacola and \#sharecoke (Nikolinakou \& Phua, 2020).

Unsurprisingly, brand managers change their mindset and adopt new strategies to cultivate and stimulate consumer online responses (Kohli et al., 2015), and elicit voluntary interactions of consumers with brand -related content on social media. This type of engagement that support the behavioural manifestation perspective (van Doorn et al., 2010) is a critical element in brand strategy and an indicator of brand performance. It is also used as a quantitative measure of social media engagement (Mishra, 2019; Schivinski et al., 2019a). Therefore, the development of brand engagement that provokes consumer's interaction and participation with the brand-related content expressed by consuming (read the content), creating, and/or contribution (like or comments) is a top priority for executives (de Vries et al., 2017; Gummerus et al., 2012; Schivinski et al., 2019b).

Brands across different industries are creating social media presence by having multiple accounts on different platforms to entice consumer participation. The interactive nature of the hosted media allows the brand to share and create content such as product information, customer services, special offers and other benefits leveraged by consumer engagement (Mishra, 2019; Simon \& Tossan, 2018). It is important to understand the drivers of online engagement to encourage and enhance consumers engagement with brand-related social media content.

Social media serves as a new communication tool with consumers that offers an alternative to traditional Web pages (Sanders et al., 2019). These social networking sites themselves work as effective tools that can entice consumer engagement with brand-related content which either generated by the firm or users (Mishra, 2019; Schivinski, 2019a). Since the user interactivity; the ability to personalise information, initiate, sustain, reply and exchange message, is rooted in the features of the medium (engagement platform). At the very basic level, most micro-blogging platforms allow users to communicate with messages and posts but with limited capabilities, for example Twitter provides its users with limited interactive tools (Sanders et al., 2019). However, the cognitive effort required by consumers to interact with brands on the social media engagement platform may hinder the level of participation. It is assumed that the less cognitive efforts required, the more consumers are motivated to spend a long time on social media platforms and engage with brand-related social content (Osei-Frimpong, 2019).

Notwithstanding, the literature on consumer engagement on social media platforms is getting rich, especially in the domain of brand communities (social-media based); however, most of the studies focused on the concept of engagement as a psychological multi aspects (affective, cognitive and behavioural) state. A handful of studies contributed to the accumulated knowledge and define the aspects of consumers behavioural engagement with brand-related social media content, namely: consumption, creation and contribution (Nikolinakou \& Phua, 2020; Schivinski et al., 2016). Previous studies investigated how brand-related social media engagement is related to individual differences; demographics, self-enhancement and self-affirmation (Sabermajidi et al., 2019), personality traits (Kabadayi \& Price, 2014), level of autonomy (self-expression and socialisation) (de Vries et al., 2017), human values (Nikolinakou \& Phua, 2020) and brand related factors; brand equity (Schivinski et al., 2019b), brand value (Carlson et al., 2018) and brand social-sharing value (Simon \& Tossan, 2018), brand social media activities (Mishra, 2019), brand or social media attachment/attitude (VanMeter et al., 2018) but several important issues on behavioural engagement have not yet been discovered.

To deepen the understanding of consumer behavioural engagement, more profound research focusing on the drivers that elicit users of social media to consume, contribute, and/or create brand-related content is required (de Vries et al., 2017; Schivinski, 2019b; Simon \& Tossan, 2018). 
Engagement is a highly context-specific concept that is associated with consumer interactive experience; therefore, it is assumed that the features of social media play a key role in enhancing user's engagement (Hughes et al., 2019; Voorveld et al., 2018)(Voorveld et al., 2018).

To date, no research has examined how the embedded characteristics of social media platform that enable its interactive nature and create user experiences will motivate consumers to engage with brand-related content. Given the increasing investments of companies in developing social media marketing strategies, it is also of importance for managers to consider the characteristics of the hosting media of brand content and its effect on consumer engagement to optimise brand strategies.

This research fills the gap in the literature by providing a theoretical model to examine the motives that stimulate consumers to engage in brand-related social media activities. In this model, the concept of engagement is proposed as a behavioural outcome of consumer's holistic experiences with online platforms, which is reflective to the semantic and technical success of social media channels.

This paper is structured as follows: in the next section, the theoretical background of this research is discussed. Then a set of research hypotheses are proposed that depict the relationships between constructs constituting the proposed model. This is followed by a description of the field study design and the study results. Finally, the conclusion, implications, limitations and future research of the study are discussed.

\section{THEORETICAL BACKGROUND}

\section{CESBC}

The ongoing interest of academics in studying the concept of engagement along the last two decades has to a great extent unclear the ambiguity associated before. The process of engagement was first introduced in the relationship marketing literature to provide an understanding of the development and evaluation of customer-brand relationships motivated by experiences with the brand (https://dictionary. cambridge.org, 2020). Successively, the construct of "engagement" had gained increased prominence in the Cambridge English Dictionary, the word engagement refers to interest and defined as "the fact of being involved with something" (van Doorn et al., 2010). As suggested, the conceptual roots of engagement go beyond the core economic transactions to capture the non-transactional behaviour of customers. Engagement differs from other attitudinal constructs such as trust, commitment and satisfaction, it is a behavioural expression that encompasses co-creation and reflects consumers strong connections with the company's offerings and interactive experiences (Passer \& Smith, 2009). According to psychology, engagement is the observed behaviour or response which reflects individual's intrinsic motivations (Dessart et al., 2015).

There is consistency among the majority of scholars that engagement is a multi-dimensional concept that delineates consumer interactive experiences with other consumers and/or other actors in the brand network. However, there is no conformity to the aspects that describe the state of engagement; generally, it can be categorised into four groups: affective, cognitive, behavioural, and social. The affective dimension reflects consumers overall enduring feelings, moods and emotions experienced with the focal object of engagement, its descriptive aspects are enthusiasm, enjoyment (Dwivedi, 2015) and dedication (Dwivedi, 2015; Mollen \& Wilson, 2010). Cognitive engagement refers to experiences with the focal engaging object that inspires the consumer's creative thinking and conscious mental process, this aspect is depicted by instrumental value (Dwivedi, 2015), absorption (Dessart et al., 2015) and attention (Dwivedi, 2015; Hollebeek et al., 2014). Behavioural engagement defines consumer's participation in activities related to the brand; the amount of energy, effort and time consumed and willingly invested in maintaining a degree of interaction with any object (Lee et al., 2011). The behavioural engagement breeds social engagement, which theoretically is based on social identity theory; that presumes consumers are engaging in interactive platforms to enhance their self-concept and feel a sense of belonging to group members (Bowden, 2009a, 2009b). 
Consumer interaction can be applied to a broad range of objects such as brands (Algesheimer et al., 2005), online brand communities (Hollebeek, 2011)however, the aspects of engagement varied subject to the context (Schivinski et al., 2016). The focal engagement object in this study is the social media brand-related content rather than the brand per se.

Consumer online brand-related activities (COBRA) are defined as efforts which describe consumer engagement with the brand content at different levels of interaction (Schivinski et al., 2016a, p.66). Based on the COBRA framework, the concept of consumer engagement with social media brand-related content (CESBC) is extended and can be defined as "a set of brand-related online activities on the part of the consumer that vary in the degree to which the consumer interacts with social media and engages in the media content" Shao, (2009). In this essence, Schivinski et al., (2016a) proposes three forms through which users interact with the user generated media (UGM): first, consuming refers to passive users who do not participate but watch, read, or view; second, participating includes interactions between the user and another user or the content in the form of posting comments and sharing, and finally, producing which involves the creation and publication of the user personal contents such as text, video, and images. Subsequently, (Mishra, 2019; Schivinski et al., 2016) identifies the three dimensions of CESBC that demonstrate different levels of behavioural engagement ranging from low to high levels.

Consumption, this dimension identifies the passive type of consumers with a minimum level of engagement with the brand-related content on social media either generated by users or the firm, such as watching the brand's pictures or videos. This type of brand-related activity is widely predominant and undistinctive to the source (Mishra, 2019; Schivinski et al., 2016, 2019b).

Contribution, this level of engagement is higher than the previous one, it shows different forms of peer-to-peer and peer-to-content interactions about the brand and does not differentiate between source of content either generated by the firm or another user. It comes in the form of liking, sharing and commenting on brand-related posts on social media (Mishra, 2019; Schivinski, 2019b; Schivinski et al., 2016).

Creation, active consumers take part in the co-creation process and generate content about the brands on social media to demonstrate the highest levels of engagement. Those consumers are taking initiatives to upload a picture or a video of their favourite brand and/or write a post or a review of the brand. The consumer generated content acts as stimulus for other consumers; it motivates them to consume or contribute to their produced content (Agarwal \& Karahanna, 2000).

\section{CONCEPTUAL FRAMEWORK AND HYPOTHESES DEVELOPMENT}

To understand the drivers of consumer engagement with social media brand-related content, the proposed model focuses on how the perceived quality of social media channels hosting brand pages shape consumer's extrinsic and intrinsic beliefs and affect their intentions to use social media and engage in brand related activities. The model is built on the extension of both TAM and the D\&L IS Model to examine the drivers of consumer engagement. It thus proposes engagement as a behavioural outcome of the consumer's acceptance to social media and a reflection of the platform semantic and technical success with the mediation of cognitive absorption. The technology acceptance model is one of the most validated theories that plays an important role in explaining consumer behaviour towards technology (Yang et al., 2017). Additionally, the DeLone and McLean IS success model will assess the factors that enhance the quality of social media channels. And cognitive absorption will explain how consumer's extrinsic beliefs are shaped and motivate their behaviours. Accordingly, the study will investigate the effects of consumer extrinsic and intrinsic beliefs, the characteristics of social media sites and consumer holistic experiences with an interactive platform on the engagement behaviour of consumer with brand-related content.

The proposed theoretical model is depicted in figure 1 . 


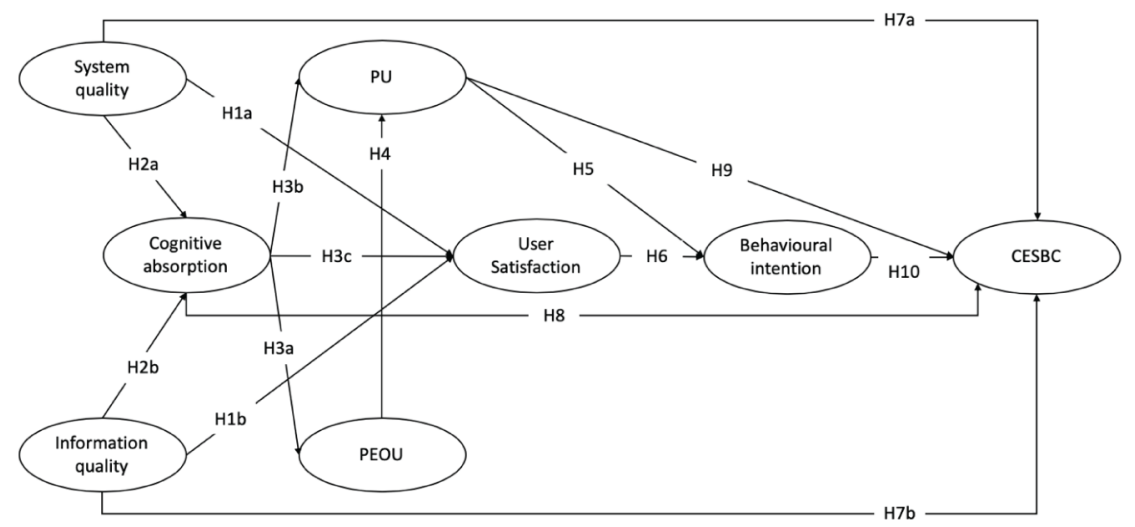

\section{Cognitive Absorption}

Cognitive absorption (CA) is defined as the state of deep involvement that captures consumer's holistic interactive experiences on social media sites. The state of absorption is exhibited through three dimensions. Temporal dissociation, the inability of users to register the passage of time while engaged in interaction. Focused immersion, the experience of total engagement in the interaction while ignoring other attention demands. Heightened enjoyment, the fun and pleasure aspects of interaction (Agarwal \& Karahanna, 2000).

Drawing on individual psychology and user behaviour of information technology, the following can be extrapolated about the concept of CA. Firstly, CA is an intrinsic motive that forms the link between behaviours and experiences of fun, pleasure and satisfaction inherited in the act itself (Hsu $\&$ Lin, 2017). Secondly, the experience of using a system is autotelic; i.e., the value of an activity is the driver of engagement. Thirdly, this state is characterised by loss of self-consciousness and responsiveness for achieving goals; thus, enhancing self-efficacy Fishbein \& Ajzen, (1975). Finally, consumer's attitudes and behaviours toward technology are affected by internal beliefs of the holistic experiences.

\section{The Delone and Mclean Model}

The success of I/S is assessed by the system usage as posited by D\&M (1992), an individual's attitude and subsequent behaviour are subject to his beliefs of system quality and information quality. The actual behaviour is defined as the net benefits of using the system, for example continued use and value of usage (Chen \& Cheng, 2009), intention to reuse and loyalty (Wang, 2008), performance and user experience (Marjanovic, et al., 2016), these benefits are varied related to the context (DeLone \& McLean, 2004). The D\&M model, (1992) has been evaluated in different settings such as e-government (Wang \& Liao, 2008), banking sector (Lee \& Chung, 2009), e-commerce (Wang, 2008), online shopping (Chen \& Cheng, 2009), and online learning (Marjanovic, et al., 2016).

Traditionally, system quality measures the system's overall performance and focuses on the outcome of the user's interaction with the website (DeLone \& McLean, 2003); it is defined here as the functionality of SMS perceived by consumers (Zhang, 2010). The perceived technical quality of SMS hosting brand page or group is often concerned with navigation, accessibility, appearance, security, and interactivity (Zheng et al., 2013). Information quality measures the quality of output of an IS (DeLone \& McLean, 1992); the semantic success of the system is assessed in terms of accuracy, completeness, relevance, and consistency. It is defined here as the quality of the brand-related content created either by the user or the company (Zhang, 2010). The information provided from posts and 
discussions on brand pages provide an aid to consumers in decision making, and are perceived as high-quality (Zhang \& Watts, 2008). Low-quality information distracts consumers and wastes their time and efforts, this information is delivered through outdated and unreliable posts or biased and misleading discussions ( $\mathrm{Gu}$ et al., 2007). Information quality is shaped by four dimensions: accuracy represents the correctness of information, completeness (Lin, 2008; Wixom \& Todd, 2005).

\section{Delone and Mclean Model and CA}

The perceived qualities in the D\&M model: system quality and information quality, measure the technical and semantic success of social media channels, respectively (Ghasemaghaei, 2020). The interactivity of consumers with the system generates their experiences and reflects their perception of its effectiveness (Tam \& Oliveira, 2017), a system with poor quality requires a user to exert more effort and frustrate his experiences (Chandra \& Srivastava, 2009). In a virtual community, the consumer's favourableness of its features and characteristics will encourage them to spend time and immerse in using (Baker et al., 2017); hence, experience the feelings of enjoyment and pleasure (Hsu \& Lin, 2017; Saadé \& Bahli, 2005).

In human-computer interactions, the clarity of guidelines and instructions encourage user curiosity, control and flow (Saadé \& Bahli, 2005), and this relationship has been supported in online learning Agarwal \& Karahanna, (2000). The social media offer various web technologies to consumer such as generation or customisation of content by the aid of audio-visual effects. Accordingly, the success of the social media platform in absorbing consumers to spend time and experiencing and engaging with brand-related content depends to a great extent on their perception of quality. The overall quality features of social media define its ability to satisfy the users and induces a state of CA.

H1: Perceived system quality (a) and information quality (b) will have a positive direct impact on satisfaction.

H2: Perceived system quality (a) and information quality (b) will have a positive direct impact on CA.

\section{TAM}

The theory of technology acceptance (TAM) is based on the principles adopted from the paradigm of (Fishbein \& Ajzen, 1975), which specifies how the features of an external stimulus are causally linked to perceptions, attitudes and behaviour. It differentiates between two attitudinal constructs: attitude toward an object and attitude toward the behaviour, the former refers to an individual's affective evaluation of a specified object, while the second defines the individual's evaluation of a specified behaviour that involves the object. The proposed TAM uses the generic definition of attitude toward the usage of IT Davis et al., (1989), and posits that the actual use of a person is influenced by behavioural intentions, which are affected by attitudes and beliefs: perceived ease of use and perceived usefulness. Perceived ease of use (PEOU) refers to the degree to which a person believes that the use of technology is effortless, this is essential to initially accept it. Perceived usefulness (PU) refers to the degree to which the prospective person believes that using technology would increase his performance, it constitutes the strongest predictor of a person's intentions (Agarwal \& Karahanna, 2000; Saadé \& Bahli, 2005). To predict intentions and behaviours accurately, user satisfaction was added to the model (Hsu \& Lin, 2017; Saadé \& Bahli, 2005).

In this study, the TAM is extended to explain consumer behavioural engagement in the context of social media. To adapt the TAM to the social media context, the use of social media channels is the outcome, the PU reflects the extent to which the user believes that using social media will help meet his goal-driven needs, and the ease of use implies the degree to which social media are effortless Agarwal \& Karahanna, (2000). A handful of studies depend on TAM to understand consumer attitudes and behaviours toward social media channels. (Alalwan et al., 2017) revised the TAM and support the significant effect of trustworthiness in addition to the model key variables in considering user 
engagement with social media. (Hsu \& Lin, (2017) and Reychav \& Wu, (2015), demonstrated the mediating role of PU in the relationship between privacy and intrusiveness concerns, and consumer attitudes toward sponsored advertising. The significant effects of PU and perceived ease-of-use on consumer attitudes toward advertisements were also supported (Agarwal \& Karahanna, 2000), and green purchase decision (Leong, 2011; Sharman et al., 2009); while, (Davis, 1993; Davis et al., 1989) revealed their ability to influence millennials' attitudes and intentions to join a brand fan page and consecutive purchase intention. Whereas, (Islam \& Rahman, 2017) found that attitudes towards engaging with a retailer fan page on social media are not influenced by the PU. The successful utilisation of the TAM on social media has been supported, therefore, the current study adopts it to understand consumer behavioural engagement.

\section{TAM and CA}

To capture consumer's holistic experience with technology, (Jang et al., 2008) propose CA as an antecedent of beliefs about technology use in TAM. According to (Islam \& Rahman, 2017; Pletikosa Cvijikj \& Michahelles, 2013), perceived ease-of-use refers to the user's assessment that interactions with technology is effortless and does not constitute a cognitive burden. CA exhibits its impact on ease-of-use through its three dimensions namely: temporal dissociation, focused immersion and heightened enjoyment. User deeply involved in a task through technological interactions will devote much of his cognitive efforts for its completion to the extent that he will lose the track of time; specially, if enjoyment is experienced (Pletikosa Cvijikj \& Michahelles, 2013). The relationship between CA and PEOU has been supported in prior studies in various settings (Kabadayi \& Price, 2014).

H3a: CA will have a positive direct impact on PEOU.

(Agarwal \& Karahanna, 2000) draw on the theory of cognitive dissonance and self-perception theory to explain the relationship between CA and PU. Cognitive dissonance refers to the psychological state of rationalising inconsistent cognitive structures; therefore, to reduce the inconsistency between competing cognitions; the pleasure of the act versus the time spent, users tend to count on its outcome. CA includes the hedonic experiences from interaction with technology during time and eventually the captured values. It is thus assumed that the dimensions of CA will positively influence PU. It has been registered that the average daily usage of consumers on social media worldwide is around two hours and a half per day; social media are thus perceived as source of entertainment, communication, information and self-identification (Dessart et al., 2015). Therefore, the instrumental value and extended benefits of social media can reduce the state of cognitive dissonance. This relationship has been demonstrated by (de Vries et al., 2017).

H3b: CA will have a positive direct impact on PU.

In the attitude-belief-intention model, CA is integrated to influence user's beliefs, intentions and behaviours through its dimensions; the experienced heightened enjoyment, temporal dissociation and focused immersion, to reduce cognitive workload and maximise the perceived value of technology usage (Agarwal \& Karahanna, 2000). CA is derived from the state of flow and cognitive engagement, which describe the time lapse when users are experiencing flow; while, the pleasure and satisfaction are inherent in the activity. Consumers spending most of their time on social media are engaging and participating in satisfactory activities. The significant effect of CA on satisfaction in virtual communities was supported by (Rauniar et al., 2014).

H3c: CA will have a positive direct impact on satisfaction. 


\section{Antecedents of Behavioural Intentions}

Behavioural intentions are the evaluative affect toward the execution of a specific behaviour. According to the Theory of Reasoned Action (TRA), upon which the TAM is extended, behaviours are determined by intentions which in turn are affected by the person's attitude. Attitude mediates the relationship between the person's beliefs and intentions (de Vries et al., 2017). The original TAM model postulates the significant impact of PEOU on usefulness, which in turn influences the person's behavioural intentions.

H4: PEOU will have a positive direct impact on PU.

H5: PU will have a positive direct impact on behavioural intentions.

H6: Satisfaction will have a positive direct impact on behavioural intentions.

\section{Antecedents of CESBC}

The drivers of consumer engagement on social media brand-related content are argued to exist at different levels. The Web 2.0 platform facilitates the interactivity of users and the adoption of the D\&L model is used to reflect the accuracy and efficiency of channel technicalities; i.e., perception of the system and information quality. Both are presumed to be efficient means for driving consumer engagement. An effective system presents accurate, complete and timely information with the respect of being user friendly Yang et al., (2017). The characteristics of an online portal hosting brand communities play an important role in motivating the consumer towards maintaining a long-term relationship with members. Hence, consumers are willing to participate in an accessible online portal McLean, (2018) to enjoy Web and company's services, collect and exchange information (Chen \& Cheng, 2009; Tam \& Oliveira, 2016). The characteristics of the content posted (informative or entertaining) affect consumer behavioural engagement; however, the quality of the content depends to a great extent on the operating mechanism of the host (Davis et al., 1989; Lin \& Kim, 2016).

H7a: System quality will have a positive direct impact on CESBC.

H7b: Information quality will have a positive direct impact on CESBC.

Highly engaged consumers with brands on social-media are acting as brand's agents and tend to have high levels of openness to experience Saadé \& Bahli, (2005). Drawing on the synopsis of CA, it can be argued that the trait of absorption; it describes the state of being perceptually engrossed in experience, is an intrinsic driver of engagement. An individual is allocating and consuming his attentional resources to the object of interest (Schivinski et al., 2016). Proactive consumers are engaging with brand-related content through the acts of sharing, learning, or endorsing to exchange and improve their experiences Tabachnick et al., (2007). Additionally, CA includes the state of flow, or the enjoyment experienced from an activity, which is the core underlying motivation for engagement in brand-related activities. Consumers tend to engage in fun and enjoying social media activities, outweighing other outcomes (Podsakoff et al., 2003). This state of absorption that encompasses high levels of interests, curiosity and attention towards an object is an outcome of the interactivity nature of the media Hair et al., (2014).

H8: CA will have a positive direct impact on CESBC.

Based on the theoretical background of the TAM model, PU is the strongest predictor of users' intentions and behaviours. All relationships of the TAM were supported in the context of social media in prior studies such as the study of Islam \& Rahman, (2017), who examined the TAM model on Facebook. Many benefits can result from consumer's interactions on social media channels that 
can act as intrinsic stimulants such as entertainment, self-expressions and satisfaction, or extrinsic stimulants in the form of rewards, information (Jang et al., 2008; Mishra, 2019; Pletikosa Cvijikj \& Michahelles, 2013; Zaglia, 2013). (Mishra, 2019) support the significant positive influence of PU on user's intention of engagement and brand attitude in the gamified branding process; additionally, (Lin, 2007) assert that utilitarian aspects of mobile apps such as PU are more influential to engagement than hedonic.

H9: PU will have a positive direct impact on CESBC.

H10: Behavioural intentions will have a positive direct impact on CESBC.

\section{RESEARCH METHODS}

The nature of this research falls in the domain of the positivist methodological paradigm, this approach endeavours the use of a deductive process to examine the causal relationships formulated out of the existing theories. Following the quantitative approach, data was collected and analysed and the developed hypotheses were tested. In terms of unit of analysis, the study depends on the consumers using various SM sites and following brand pages or groups either created by the firm or the users. This approach is illustrated diagrammatically in figure 2 (Appendix A).

\section{Sample and Data Collection}

The survey was developed using Qualtrics and the responses were screened through two questions and only respondents who answered yes were allowed to participate in the study. The participants were recruited on a referral basis of being English citizens or residents and following brands on social media sites. The questionnaire consists of two sections: the first section includes questions concerning about the respondents' demographics and their experiences with social media sites and the second section comprises questions relating to the study constructs. Respondents were advised to select a brand they are fans of and following it on social media sites and to keep it in mind while completing the questionnaire. The results show that the majority of the selected brands belong to these product categories: clothing, bags and shoes, cars, sports and leisure, cosmetics and personal care and electronics.

A convenience sampling approach was used, the link of the questionnaire was spanned over a period of five months through social media sites such as WhatsApp, Facebook, Twitter, or LinkedIn. Due to low response rate, 206 responses, mall-intercept was also applied. Over a period of two weeks during February, 2019, participants were approached in shopping malls in the UK, 160 valid responses were collected with a response rate of $72 \%$. The sample consists of 129 males (37\%) and 219 females (63\%), further details regarding the sample demographics and characteristics are provided in tables 1 and 2 .

\section{Measures}

All measurement scales were drawn from previous research. The measurement scales of system quality (navigation, accessibility, appearance, privacy and interactivity), information quality (accuracy, completeness, currency, reliability and format) and satisfaction were gauged based on the work of Rauniar et al., (2014). The scales for measuring PU, PEOU and behavioural intentions were adapted from (Agarwal \& Karahanna, 2000). CA is second-order construct, assessed by the fourteen items scale of (Agarwal \& Karahanna, 2000; Barnes et al., 2019; Hsu \& Lin, 2017; Lin, 2009; Reychav \& Wu, 2015; Saadé \& Bahli, 2005); four items were selected for temporal dissociation, three items including a reversed item were selected for heightened enjoyment and finally focused immersion was measured by three items as well. In addition, CESBC is a second order measured by three dimensions: 
Table 1. Sample demographics

\begin{tabular}{|c|c|c|c|}
\hline Variable name & Values & Frequency & Valid Percentage \\
\hline Gender & $\begin{array}{l}\text { Male } \\
\text { Female }\end{array}$ & $\begin{array}{l}129 \\
219\end{array}$ & $\begin{array}{l}37.1 \% \\
62.9 \%\end{array}$ \\
\hline Age & $\begin{array}{l}18-29 \\
30-39 \\
40-49 \\
50^{+}\end{array}$ & $\begin{array}{l}138 \\
113 \\
76 \\
22\end{array}$ & $\begin{array}{l}39.5 \% \\
32.4 \% \\
21.8 \% \\
6.3 \%\end{array}$ \\
\hline Level of education & $\begin{array}{l}\text { High school } \\
\text { Bachelor degree } \\
\text { Master degree } \\
\text { Doctoral degree } \\
\text { Other }\end{array}$ & $\begin{array}{l}57 \\
105 \\
114 \\
49 \\
25\end{array}$ & $\begin{array}{l}16.3 \% \\
30.0 \% \\
32.6 \% \\
14.0 \\
7.1 \%\end{array}$ \\
\hline Job status & $\begin{array}{l}\text { Full-time } \\
\text { Part-time } \\
\text { Unemployed } \\
\text { Retired } \\
\text { Student } \\
\text { Housewife }\end{array}$ & $\begin{array}{l}150 \\
70 \\
28 \\
9 \\
62 \\
31\end{array}$ & $\begin{array}{l}42.9 \% \\
20.0 \% \\
8.0 \% \\
2.6 \% \\
17.7 \% \\
8.9 \%\end{array}$ \\
\hline Nationality & $\begin{array}{l}\text { British } \\
\text { Non-British/UK resident }\end{array}$ & $\begin{array}{l}224 \\
125\end{array}$ & $\begin{array}{l}64 . \% \\
34.2 \%\end{array}$ \\
\hline Ethnic group & $\begin{array}{l}\text { White } \\
\text { White British } \\
\text { Black } \\
\text { Asian } \\
\text { Mixed } \\
\text { Other } \\
\text { Prefer not say }\end{array}$ & $\begin{array}{l}93 \\
17 \\
5 \\
33 \\
13 \\
77 \\
10\end{array}$ & $\begin{array}{l}37.5 \% \\
6.9 \% \\
2.0 \% \\
13.3 \% \\
5.2 \% \\
31.0 \% \\
4.0 \%\end{array}$ \\
\hline Province & $\begin{array}{l}\text { England } \\
\text { Scotland } \\
\text { Northern Ireland } \\
\text { Wales }\end{array}$ & $\begin{array}{l}222 \\
7 \\
2 \\
1\end{array}$ & $\begin{array}{l}95.7 \% \\
3.0 \% \\
0.9 \% \\
0.4 \%\end{array}$ \\
\hline
\end{tabular}

Table 2. Sample characteristics

\begin{tabular}{|l|l|l|l|}
\hline \multicolumn{1}{|c|}{ Variable name } & \multicolumn{1}{|c|}{ Values } & \multicolumn{1}{c|}{ Percentage } \\
\hline \multirow{4}{*}{ Experience with SM sites } & < a year & 17 & $4.6 \%$ \\
& $1-5$ year & 47 & $12.8 \%$ \\
& $6-10$ year & 101 & $27.6 \%$ \\
& $10^{+}$year & 80 & $21.9 \%$ \\
\hline & Facebook & 133 & $36.3 \%$ \\
& Twitter & 16 & $4.4 \%$ \\
& LinkedIn & 14 & $6.0 \%$ \\
& Instagram & 63 & $26.9 \%$ \\
& Other (Snapchat) & 8 & $3.4 \%$ \\
\hline \multirow{5}{*}{ Frequently used SM channel } & Almost everyday & 90 & $24.6 \%$ \\
& > once a week & 59 & $16.1 \%$ \\
& > once a month & 47 & $12.8 \%$ \\
& > once in 3 months & 21 & $5.7 \%$ \\
& Whenever I need & 149 & $40.7 \%$ \\
\hline
\end{tabular}


consumption, contribution and creation developed by (Reychav \& Wu, 2015). All the questions were measured using 7-points Likert scale ranging from (1) strongly disagree to (7) strongly agree.

\section{DATA ANALYSIS AND RESULTS}

\section{Measurement Model, Reliability and Validity}

Factor analysis was used to identify the variables and dimensions, Exploratory factor analysis (EFA) was conducted using SPSS 26.0. The factorability of data was tested using Bartlett's test of sphericity and Kaiser-Meyer-Olkin (KMO), the results meeting the threshold suggested by (Hsieh et al., 2008). The VARIMAX orthogonal rotation approach was used and the results revealed the loading of items on nine factors as shown in the Appendix B, the ten items measuring items CESBC were loaded on three factors composing its dimensions, Appendix C. Furthermore, Harman's single factor test supports the inexistence of common method bias, with variance $<50 \%$ Yang et al., (2017).

Using the Confirmatory factor analysis (CFA), AMOS 24, the fit of the measurement model and the construct validity were assessed. With the cut-offs suggested by McLean, (2018), the results yielded an adequate fit with values; $(\chi 2=2045.352, \mathrm{df}=923, \chi 2 / \mathrm{df}=2.216, \mathrm{IFI}=0.949, \mathrm{CFI}=0.949$, RMSEA $=0.05)$. The factor loading of all items was above 0.5 at significant t-values, the internal consistency was considered good, and the minimum value of the average variance extracted is 0.73 ; thus, validating the convergent validity. The results are shown in table 3 , which verify the discriminant validity of the model's constructs. Table 4 exhibits that both Cronbach alpha and composite reliability are above the threshold of 0.7 indicating acceptable reliability.

\section{Structural Model}

To test the relationships between constructs as hypothesised in the proposed model, table 5, SEM was used for hypotheses testing. The results yielded an adequate level of fit $(\chi 2=1215.81, \mathrm{df}=4468$, $\chi 2 / \mathrm{df}=2.71, \mathrm{IFI}=0.94, \mathrm{CFI}=0.94, \mathrm{RMSEA}=0.06)$. The model explains $62.8 \%$ of $\mathrm{CA}$ and $39.1 \%$ of variation in CESBC.

\section{Table 3. Average variance extracted and construct correlations}

\begin{tabular}{|c|c|c|c|c|c|c|c|c|c|c|c|c|c|}
\hline & SYSQ & INFa & TD & HE & F1 & SAT & PEOU & PU & BI & CSP & CON & CRT & AVE \\
\hline SYSQ & 1 & & & & & & & & & & & & 0.78 \\
\hline INFQ & 0.758 & 1 & & & & & & & & & & & 0.85 \\
\hline TD & 0.473 & 0.499 & 1 & & & & & & & & & & 0.91 \\
\hline $\mathrm{HE}$ & 0.543 & 0.513 & 0.506 & 1 & & & & & & & & & 0.79 \\
\hline FI & 0.330 & 0.372 & 0.487 & 0.393 & 1 & & & & & & & & 0.90 \\
\hline SAT & 0.704 & 0.740 & 0.450 & 0.479 & 0.451 & 1 & & & & & & & 0.88 \\
\hline PEOU & 0.557 & 0.553 & 0.447 & 0.496 & 0.35 & 0.499 & 1 & & & & & & 0.87 \\
\hline PU & 0.539 & 0.523 & 0.372 & 0.453 & 0.336 & 0.445 & 0.715 & 1 & & & & & 0.91 \\
\hline BI & 0.169 & 0.258 & 0.260 & 0.326 & 0.293 & 0.219 & 0.311 & 0.300 & 1 & & & & 0.69 \\
\hline CSP & 0.436 & 0.417 & 0.457 & 0.407 & 0.333 & 0.387 & 0.501 & 0.485 & 0.243 & 1 & & & 0.73 \\
\hline CON & 0.043 & 0.147 & 0.169 & 0.097 & 0.048 & 0.057 & 0.114 & 0.119 & 0.203 & 0.362 & 1 & & 0.78 \\
\hline CRT & -0.05 & -0.019 & 0.046 & 0.045 & -0.016 & -0.010 & -0.036 & -0.017 & 0.062 & 0.225 & 0.617 & 1 & 0.81 \\
\hline
\end{tabular}


International Journal of Customer Relationship Marketing and Management

Volume $13 \cdot$ Issue 1

Table 4. Descriptive statistics of first order construct, factor loading and reliability test

\begin{tabular}{|c|c|c|c|c|c|}
\hline & Mean & S.D. & Factor Loading & Cronbach alpha & CR \\
\hline SYSQ1 & 4.27 & 1.95 & 0.943 & \multirow{5}{*}{0.947} & \multirow{5}{*}{0.948} \\
\hline SYSQ2 & 4.19 & 1.91 & 0.954 & & \\
\hline SYSQ3 & 4.25 & 1.89 & 0.947 & & \\
\hline SYSQ4 & 4.42 & 1.63 & 0.701 & & \\
\hline SYSQ5 & 4.27 & 1.83 & 0.867 & & \\
\hline INFQ1 & 4.55 & 1.74 & 0.918 & \multirow{5}{*}{0.967} & \multirow{5}{*}{0.967} \\
\hline INFQ2 & 4.48 & 1.68 & 0.932 & & \\
\hline INFQ3 & 4.44 & 1.83 & 0.922 & & \\
\hline INFQ4 & 4.46 & 1.76 & 0.932 & & \\
\hline INFQ5 & 4.45 & 1.77 & 0.918 & & \\
\hline SAT1 & 4.35 & 1.61 & 0.878 & \multirow{4}{*}{0.967} & \multirow{4}{*}{0.967} \\
\hline SAT2 & 4.35 & 1.65 & 0.954 & & \\
\hline SAT3 & 4.28 & 1.65 & 0.956 & & \\
\hline SAT4 & 4.28 & 1.75 & 0.964 & & \\
\hline TD1 & 4.40 & 1.85 & 0.934 & \multirow{4}{*}{0.979} & \multirow{4}{*}{0.978} \\
\hline TD2 & 4.36 & 1.89 & 0.952 & & \\
\hline TD3 & 4.31 & 1.92 & 0.976 & & \\
\hline TD4 & 4.36 & 1.88 & 0.973 & & \\
\hline HE1 & 4.79 & 1.96 & 0.961 & \multirow{3}{*}{0.915} & \multirow{3}{*}{0.921} \\
\hline HE2 & 4.9 & 1.77 & 0.714 & & \\
\hline HE3 & 4.81 & 1.99 & 0.982 & & \\
\hline FI1 & 4.46 & 1.64 & 0.906 & \multirow{3}{*}{0.966} & \multirow{3}{*}{0.966} \\
\hline FI2 & 4.43 & 1.64 & 0.986 & & \\
\hline FI3 & 4.49 & 1.60 & 0.963 & & \\
\hline PEOU1 & 4.21 & 1.71 & 0.930 & \multirow{4}{*}{0.966} & \multirow{4}{*}{0.96} \\
\hline PEOU2 & 4.09 & 1.63 & 0.937 & & \\
\hline PEOU3 & 4.17 & 1.66 & 0.940 & & \\
\hline PEOU4 & 4.18 & 1.83 & 0.941 & & \\
\hline PU1 & 4.46 & 1.77 & 0.933 & \multirow{4}{*}{0.977} & \multirow{4}{*}{0.977} \\
\hline PU2 & 4.48 & 1.75 & 0.958 & & \\
\hline PU3 & 4.44 & 1.80 & 0.976 & & \\
\hline PU4 & 4.56 & 1.82 & 0.958 & & \\
\hline BI1 & 4.45 & 1.44 & 0.799 & \multirow{4}{*}{0.900} & \multirow{4}{*}{0.899} \\
\hline BI2 & 4.54 & 1.48 & 0.800 & & \\
\hline BI3 & 4.33 & 1.53 & 0.853 & & \\
\hline BI4 & 4.35 & 1.52 & 0.870 & & \\
\hline
\end{tabular}




\begin{tabular}{|c|c|c|c|c|c|}
\hline & Mean & S.D. & Factor Loading & Cronbach alpha & CR \\
\hline CSP1 & 4.28 & 1.64 & 0.876 & \multirow{3}{*}{0.891} & \multirow{3}{*}{0.893} \\
\hline CSP2 & 4.43 & 1.61 & 0.772 & & \\
\hline CSP3 & 4.28 & 1.69 & 0.921 & & \\
\hline CON1 & 4.38 & 1.65 & 0.948 & \multirow{4}{*}{0.945} & \multirow{4}{*}{0.933} \\
\hline $\mathrm{CON} 2$ & 4.41 & 1.60 & 0.918 & & \\
\hline CON3 & 4.48 & 1.59 & 0.845 & & \\
\hline CON4 & 4.52 & 1.55 & 0.813 & & \\
\hline CRT1 & 4.50 & 1.71 & 0.950 & \multirow{3}{*}{0.931} & \multirow{3}{*}{0.929} \\
\hline CRT2 & 4.50 & 1.67 & 0.931 & & \\
\hline CRT3 & 4.34 & 1.69 & 0.823 & & \\
\hline
\end{tabular}

Table 5. Hypotheses testing

\begin{tabular}{|c|c|c|c|c|}
\hline Relationship & $\begin{array}{l}\text { Standardised } \\
\text { estimated }\end{array}$ & T-Value & $\mathbf{P}$ & $\mathbf{R}^{2}$ \\
\hline $\begin{array}{l}\text { H1a: System quality } \rightarrow \text { satisfaction } \\
\text { H1b: Information quality } \rightarrow \text { satisfaction }\end{array}$ & $\begin{array}{l}0.246 \\
0.396\end{array}$ & $\begin{array}{l}3.781 \\
5.981\end{array}$ & .000 & 0.613 \\
\hline $\begin{array}{l}\text { H2a: System quality } \rightarrow \text { CA } \\
\text { H2b: Information quality } \rightarrow \text { CA }\end{array}$ & $\begin{array}{l}0.419 \\
0.427\end{array}$ & $\begin{array}{l}5.273 \\
5.343\end{array}$ & $\begin{array}{l}.000 \\
.000\end{array}$ & 0.628 \\
\hline $\begin{array}{l}\mathrm{H} 3 \mathrm{a}: \mathrm{CA} \rightarrow \mathrm{PEOU} \\
\mathrm{H} 3 \mathrm{~b}: \mathrm{CA} \rightarrow \mathrm{PU} \\
\mathrm{H} 3 \mathrm{c}: \mathrm{CA} \rightarrow \text { satisfaction }\end{array}$ & $\begin{array}{l}0.707 \\
0.264 \\
0.212\end{array}$ & $\begin{array}{l}9.081 \\
3.775 \\
2.707\end{array}$ & $\begin{array}{l}.000 \\
.000 \\
.007\end{array}$ & \\
\hline $\mathrm{H} 4: \mathrm{PEOU} \rightarrow \mathrm{PU}$ & 0.528 & 8.441 & .000 & \\
\hline $\begin{array}{l}\text { H5: PU } \rightarrow \text { behavioural intentions } \\
\text { H6: Satisfaction } \rightarrow \text { behavioural intentions }\end{array}$ & $\begin{array}{l}0.255 \\
0.108\end{array}$ & $\begin{array}{l}4.245 \\
1.804\end{array}$ & $\begin{array}{l}.000 \\
.071\end{array}$ & 0.101 \\
\hline $\begin{array}{l}\text { H7a: System quality } \rightarrow \text { CESBC } \\
\text { H7b: Information quality } \rightarrow \text { CESBC }\end{array}$ & $\begin{array}{l}-0.073 \\
-0.098\end{array}$ & $\begin{array}{l}-0.753 \\
-1.006\end{array}$ & $\begin{array}{l}.451 \\
.314\end{array}$ & \multirow{4}{*}{0.391} \\
\hline H8: CA $\rightarrow$ CESBC & 0.614 & 3.983 & .000 & \\
\hline H9: PU $\rightarrow$ CESBC & 0.158 & 2.097 & .036 & \\
\hline H10: Behavioural intentions $\rightarrow$ CESBC & 0.056 & 1.026 & .305 & \\
\hline
\end{tabular}

The results show that the system quality and information quality have a positive significant impact on satisfaction with $\beta=0.246, \mathrm{p}<0.000$, $\mathrm{t}$-value $=3.781$ and $\beta=0.396, \mathrm{p}<0.001$, $\mathrm{t}$-value $=5.981$, respectively, both explained $61.3 \%$ of variation in satisfaction; thus, H1a\&b are supported. The two quality dimensions exert a positive direct influence on CA; system quality $(\beta=0.419, \mathrm{p}<0.000$, $\mathrm{t}$-value $=5.273), \mathrm{R}^{2}=0.628, \mathrm{H} 2 \mathrm{a} \& \mathrm{H} 2 \mathrm{~b}$ are supported. $\mathrm{CA}$ has a significant direct positive impact on PEOU $(\beta=0.707, \mathrm{p}<0.000$, $\mathrm{t}$-value $=9.081), \mathrm{PU}(\beta=0.264, \mathrm{p}<0.000$, $\mathrm{t}$-value $=3.775)$ and satisfaction $(\beta=0.212, \mathrm{p}=0.007$, t-value $=2.7 .7)$; hence $\mathrm{H} 3 \mathrm{a}, \mathrm{H} 3 \mathrm{~b} \& \mathrm{H} 3 \mathrm{c}$ are supported. PEOU has a significant direct positive impact on $\mathrm{PU}(\beta=0.528, \mathrm{p}<0.000$, $\mathrm{t}$-value $=8.441), \mathrm{H} 4$ is supported. Behavioural intentions are affected by PU $(\beta=0.255, \mathrm{p}<0.000$, $\mathrm{t}$-value $=4.245), \mathrm{H} 5$; whereas, the proposed effect of satisfaction on behavioural intentions is unsupported $(\beta=0.108, p=0.71$, $\mathrm{t}$-value $=1.804)$; therefore, H6 is not supported. Finally, CESBC is affected by both $\mathrm{CA}(\beta=0.614, \mathrm{p}$ 
$<0.000$, t-value $=3.983)$ and $\mathrm{PU}\left(\beta=0.158, \mathrm{p}=0.036\right.$, $\mathrm{t}$-value $=2.097$ with $\mathrm{R}^{2}=0.39$ thus, supporting hypotheses H8 \& H9; however, the effects of system quality $(\beta=-0.073, \mathrm{p}=0.451$, $\mathrm{t}$-value $=-0.753)$ and information quality $(\beta=-0.098, \mathrm{p}=0.3140, \mathrm{t}$-value $=-1.006)$, and the behavioural intentions $(\beta=0.056, \mathrm{p}=0.305$, $\mathrm{t}$-value $=1.026)$ on CESBC are insignificant, rejecting H7a \& H7b \& H10.

\section{DISCUSSION}

The main aim of this study was to investigate the drivers of consumer engagement on social media brand-related content. An extended model of the TAM and D\&M model is used to uncover how the features of the hosting social media platform, which enhance its overall performance, CA and user's acceptance of technology, can drive consumers to engage in different activities with the brand content on social media.

Based on the results of the hypothesised relationships between the constructs in the suggested model, the direct impacts of external beliefs on behaviour were found not to be significant. Unlike previous studies, (Chandra \& Srivastava, 2009; Leong, 2011; Lin, 2007) evidenced that the characteristics of online brand communities; perceived quality (system and information), interactivity and rewards, positively influence consumer engagement. Additionally, consumers are willing to engage with the company's different communities on social media and are willing to maintain an enduring relationship due to its functionality and information quality and above all is the importance of virtual interactivity (Ghasemaghaei, 2020). Research has pointed out that the interactive features of the website and the company's marketing efforts facilitate social media engagement (Bozoglan et al., 2014; Hsu \& Lin, 2017; Sharman et al., 2009). However, in the proposed model, system quality and information quality were demonstrated to exert a significant positive impact on CA and satisfaction. These perceived qualities (system and information) that define the features of the context; media design and interactivity, in addition to being informative and secured are important in assessing its performance design and shaping the consumer's experience. Therefore, based on the findings, environmental beliefs are important antecedents that drive the state of absorption consumers can experience while interacting within a virtual context. Accordingly, highly performing systems are associated with minimal efforts and user's favourable attitudes (Saadé \& Bahli, 2005).

In essence, the TAM proposes that consumer's social media usage depends on the consequences; related benefits of using SM. In the same context, (Cao et al., 2020) demonstrated the significant impact of external benefits and utilitarian orientation of consumer perception on social media usage. However, the TAM model has long been criticised because of its limited ability in justifying how beliefs around technology are formed, and not incorporating the impact of holistic experiences with technology in understating behaviours (Cao et al., 2020). Accordingly, CA is proposed as a powerful intrinsic motivation that shapes the beliefs related to technology. The extension of the TAM to include CA has been introduced in prior studies (Reychav \& Wu, 2015); similarly, the findings of the current study support the significant direct impact of CA on PU, PEOUand satisfaction. The results reinforce the positive effect of CA on consumer's beliefs about the social media, the targeted information technology, and subsequent behaviour is supported. A plausible explanation is that the state of CA can leverage consumer's intrinsic motivation during his interactions on social media to get engaged in beneficial outcomes (Hsieh et al., 2008).

It has been proposed that the context features and consumer's state of CA and beliefs will provide an understanding of the engagement behaviour on social media brand-related content. The tested model supports the positive significant influences of CA and PU on consumer's engagement on social media with brand-related content. While, the impact of PU on behavioural intentions to use is questionable and does not ascertain engagement Yang et al., (2017), but the results of this study support the argument that consumer's beliefs of the benefits associated with interactions with social media positively affect their intentions to use and engagement behaviours. This shows consistency with McLean, (2018) they outlined that the PU is among strong predictors of consumer's intention of 
engagement in the gamification context. Similarly, (Chandra \& Srivastava, 2009; Leong, 2011; Lin, 2007) found that engagement with a retailer branded mobile application is motivated by the app's PU.

In line with prior studies, CA significantly influences attitudes (Ghasemaghaei, 2020), intentions (Bozoglan et al., 2014; Hsu \& Lin, 2017; Sharman et al., 2009), and behaviours either directly (Saadé $\&$ Bahli, 2005) or indirectly mediated by beliefs (Cao et al., 2020). Accordingly, cognitively absorbed consumers who are likely to spend time on social media platforms will engage with brand-related content; thus, maximising the possible benefits of being involved in online activities and avoid cognitive dissonance. The dimensions of CA provide a frame for consumer's interactions on social media channels; the personality trait of absorption is a key element in understanding a person's total experience with an object.

\section{CONCLUSION}

This paper aims to investigate the antecedents of CESBC by examining the social media contextual factors; unlike previous studies which were focusing on the effects of brand or consumer-related factors. Accordingly, the study deploys IS success model and goes beyond user's behavioural intentions, the proposed model defines four predictors of CESBC, namely: system quality, information quality, $\mathrm{CA}, \mathrm{PU}$ and behavioural intentions. From a theoretical perspective, this model is comprehensive as it reinforces the following:

- Expanding consumer's beliefs of the media features and information aspects to behavioural brand-related outcomes.

- Providing a theoretical explanation of the suggested causal relationships in D\&M model by integrating TAM extrinsic motivations.

- Examining the role of consumer's holistic experience on social media; gained from being deeply involved on the platform; the linkage between consumer's evaluation of social media characteristics, and his behavioural beliefs of SM usefulness and subsequent engagement behaviour.

The results assert that consumers' social media-based beliefs expressed in system quality and information quality shape their experiences and attitudes; user's social media satisfaction. These intrinsic motivations; $\mathrm{CA}$, in return contributes in influencing consumer's attitudes, behavioural beliefs and behaviours. Social media itself promote engagement; consumption, contribution, and creation, through its attributes that form consumers' experiences and their perceptions of usefulness. Given the wide array of social media platforms, this model serves as a feedback of social media effectiveness and emphases the platform attributes important in brand success.

\section{THEORETICAL IMPLICATIONS}

The first contribution of this study is the validation of the IT model in the context of social media. By drawing on the D\&M IS success model, this research defines the attributes of the external environment; the social media platform, that host the company's products, brand fan page, and enable it to communicate with consumers and provide them with services and offerings. The study highlighted the importance of contextual factors such as system quality and information quality on driving consumer's CA and shed light on the role played by the perceived utilitarian value drawn from interacting on social media platforms in the engagement of consumers with brand contents.

This study pioneers in assessing the role of CA on social media, and it exemplifies its role in driving consumes engagement with the brand-related content. CA filters out social media stimuli; that is, the externalities of the context used to motivate users towards interaction and engagement with 
activities on its platform. Accordingly, consumers will experience CA and its related psychometric properties; afterward, rationalise their behaviours. The inclusion of CA as an antecedent of consumer's perceptions plays an important role in maximising the usefulness of interacting with social media; while, capturing the totality of social media experiences. It also defines the routes that contribute to the manifestation of consumer inclination toward online activities. This study offers a new insight to the literature of CA by examining its antecedents and outcomes. through which consumers inclination to online activities is manifested.

Finally, the outcome of this study enhances the understanding of consumer engagement with brand-related content on social media by referring to the contextual characteristics. The logic behind the used IT theory is that the level of consumer's engagement with technology is reflected in net benefits, assuming that the higher the level of engagement the higher the performance. However, engagement is contingent on the system success. The success of the system is determined at many levels; accuracy and efficiency, conveying information, user's acceptance, favourable attitude and finally its effectiveness and influence. The key motivator of engagement behaviour is the CA that reflects consumer's experiences of the social media landscape and enhance the value of its' interactive nature.

\section{PRACTICAL IMPLICATIONS}

The research findings provide useful insights for brand managers seek to enhance consumer engagement on social media platform. It emphasises the role of social media in marketing communications and focuses on the aspects of behavioural online engagement.

The concept of consumer engagement on social media brand-related content encompasses two key elements, they are the hosting platform of the company's brand-related content and the multilevels behaviours. This behavioural perspective is in line with social media metrics; although, each platform has its own analytical tool, but engagement is the most common and important one used for assessing social media and the brand performance (Cao et al., 2020). Companies are making huge investments on different social media sites to claim their presence, and the key element of success is consumer engagement activities; consumption, contribution and creation, which generate profit and raises the return on investment. Therefore, there is a need to integrate SM attributes to the company's marketing strategy, especially, that these attributes drive traffic on the media channel and attract a great number of users enhancing its popularity. Social media providers should improve the technological functional capabilities; developing their provided services to achieve better user's CA and continued use of social media.

At the bottom line, the characteristics of the social media context are important to enrich the attractiveness of social media channels and trigger consumer engagement. SM marketers need to configure quality mechanisms that amplify the interactivity, upgrade the system quality and ensure information quality. Indeed, the different flavours; unique features, of social media sites can serve the different aims of marketing strategy and ensure its effectiveness; however, the interactivity nature is the common baseline. The effects of contextual factors uncovered in this study are the key drivers of various levels of consumer engagement despite the richness of the content; videos, high-quality pictures, audio, instant feedback, live interactions, provided at each communication channel.

\section{LIMITATIONS AND RECOMMENDATIONS FOR FUTURE RESEARCH}

The study has a number of limitations that offer potential future research. First, the theoretical background is focusing only on the IS success factors of the social media context, but other variables such as the differential impact of media type and its content should be considered to contribute 
more to the understanding of behavioural engagement. Second, the type of engagement examined here is adopting the consumer's perspective; while, other engagement forms with stakeholders, employees, or investors are also important to the effectiveness of brand strategy. Third, the empirical limitations of the convenience sample, the sample size inhibit testing the moderating effects of gender and age differences. 


\section{REFERENCES}

https://dictionary.cambridge.org. (2020). The Cambridge English Dictionary. https://dictionary.cambridge.org/ dictionary/english/engagement\#cald4-1-4

Agarwal, R., \& Karahanna, E. (2000). Time Flies When You're Having Fun: Cognitive Absorption and Beliefs about Information Technology Usage. Management Information Systems Quarterly, 24(4), 665. doi: $10.2307 / 3250951$

Alalwan, A. A., Rana, N. P., Dwivedi, Y. K., \& Algharabat, R. (2017). Social media in marketing: A review and analysis of the existing literature. In Telematics and Informatics (Vol. 34, Issue 7, pp. 1177-1190). Elsevier Ltd. doi:10.1016/j.tele.2017.05.008

Algesheimer, R., Dholakia, U. M., \& Herrmann, A. (2005). The Social Influence of Brand Community: Evidence from European Car Clubs. Journal of Marketing, 69.

Baker, D. S., Underwood, J. III, \& Thakur, R. (2017). Factors Contributing to Cognitive Absorption and Grounded Learning Effectiveness in a Competitive Business Marketing Simulation. Marketing Education Review, 27(3), 127-140. doi:10.1080/10528008.2017.1306710

Barnes, S. J., Pressey, A. D., \& Scornavacca, E. (2019). Mobile ubiquity: Understanding the relationship between cognitive absorption, smartphone addiction and social network services. Computers in Human Behavior, 90, 246-258. doi:10.1016/j.chb.2018.09.013

Bowden, J. (2009a). Customer engagement: A framework for assessing customer-brand relationships: The case of the restaurant industry. Journal of Hospitality \& Leisure Marketing, 18(6), 574-596. doi:10.1080/19368620903024983

Bowden, J. (2009b). The process of customer engagement: A conceptual framework. Journal of Marketing Theory and Practice, 17(1), 63-74. doi:10.2753/MTP1069-6679170105

Bozoglan, B., Demirer, V., \& Sahin, I. (2014). Problematic Internet use: Functions of use, cognitive absorption, and depression. Computers in Human Behavior, 37, 117-123. doi:10.1016/j.chb.2014.04.042

Cao, D., Meadows, M., Wong, D., \& Xia, S. (2020). Understanding consumers' social media engagement behaviour: An examination of the moderation effect of social media context. Journal of Business Research. Advance online publication. doi:10.1016/j.jbusres.2020.06.025

Carlson, J., Rahman, M., Voola, R., \& de Vries, N. (2018). Customer engagement behaviours in social media: Capturing innovation opportunities. Journal of Services Marketing, 32(1), 83-94. doi:10.1108/JSM-02-2017-0059

Chandra, S., \& Srivastava, S. (2009). Role of cognitive absorption and trust for collaboration in virtual world. Academic Press.

Chen, C. W. D., \& Cheng, C. Y. J. (2009). Understanding consumer intention in online shopping: A respecification and validation of the DeLone and McLean model. Behaviour \& Information Technology, 28(4), 335-345. doi:10.1080/01449290701850111

Clement, J. (2020, February). statista.com. https://www.statista.com/statistics/264810/number-of-monthlyactive-facebook-users-worldwide/

Davis, F. D. (1993). User acceptance and of infromation technology: System charactersitics, user perceptions and behavioral impacts. International Journal of Man-Machine Studies, 38(3), 475-487. doi:10.1006/imms.1993.1022

Davis, F. D., Bagoooi, R. P., \& Warshaa, P. R. (1989). User Acceptance of Computer Technologg: A Comparison of TTo Theoretical Models. In Source. Management Science, 35(8), 982-1003. doi:10.1287/mnsc.35.8.982

de Vries, L., Peluso, A. M., Romani, S., Leeflang, P. S. H., \& Marcati, A. (2017). Explaining consumer brandrelated activities on social media: An investigation of the different roles of self-expression and socializing motivations. Computers in Human Behavior, 75, 272-282. doi:10.1016/j.chb.2017.05.016

Dessart, L., Veloutsou, C., \& Morgan-Thomas, A. (2015). Consumer engagement in online brand communities: A social media perspective. Journal of Product and Brand Management, 24(1), 28-42. doi:10.1108/JPBM-062014-0635 
Dwivedi, A. (2015). A higher-order model of consumer brand engagement and its impact on loyalty intentions. Journal of Retailing and Consumer Services, 24(C), 100-109. doi:10.1016/j.jretconser.2015.02.007

Fishbein, H. J., \& Ajzen, I. (1975). Beleif, Attitude, Intention and Behaviour: An introduction to Theory and Research. Addison-Wesley.

Ghasemaghaei, M. (2020). The impact of in-depth online recommendation agents on consumer disorientation and cognitive absorption perceptions. Behaviour \& Information Technology, 39(4), 414-430. doi:10.1080/01 44929X.2019.1598496

Gu, B., Konana, P., Rajagopalan, B., \& Chen, H.-W. M. (2007). Competition Among Virtual Communities and User Valuation: The Case of Investing-Related Communities. Information Systems Research, 18(1), 68-85. doi:10.1287/isre.1070.0114

Gummerus, J., Liljander, V., Weman, E., \& Pihlström, M. (2012). Customer engagement in a Facebook brand community. Management Research Review, 35(9), 857-877. doi:10.1108/01409171211256578

Guttmann, A. (2018, July 19). Statista.com. https://www.statista.com/topics/1538/social-media-marketing/

Hair, J. F., Black, W. C., Babin, B. J., \& Anderson, R. E. (2014). Multivariate data analysis (7th ed.). Pearson Education Limited.

Hollebeek, L. (2011). Demystifying customer brand engagement: Exploring the loyalty nexus. In Journal of Marketing Management (Vol. 27, Issues 7-8, pp. 785-807). doi:10.1080/0267257X.2010.500132

Hollebeek, L. D., Glynn, M. S., \& Brodie, R. J. (2014). Consumer brand engagement in social media: Conceptualization, scale development and validation. Journal of Interactive Marketing, 28(2), 149-165. doi:10.1016/j.intmar.2013.12.002

Hsieh, R., Rai, , \& Keil, . (2008). Understanding Digital Inequality: Comparing Continued Use Behavioral Models of the Socio-Economically Advantaged and Disadvantaged. Management Information Systems Quarterly, 32(1), 97. doi:10.2307/25148830

Hsu, M. H., \& Lin, H. C. (2017). An investigation of the impact of cognitive absorption on continued usage of social media in Taiwan: The perspectives of fit. Behaviour \& Information Technology, 36(8), 768-791. doi:10 .1080/0144929X.2017.1288267

Hughes, C., Swaminathan, V., \& Brooks, G. (2019). Driving Brand Engagement Through Online Social Influencers: An Empirical Investigation of Sponsored Blogging Campaigns. Journal of Marketing, 83(5), 78-96. https://doi.org/10.1177/0022242919854374

Islam, J., \& Rahman, Z. (2017). The impact of online brand community characteristics on customer engagement: An application of Stimulus-Organism-Response paradigm. Telematics and Informatics, 34(4), 96-109. https:// doi.org/10.1016/j.tele.2017.01.004

Jang, H., Olfman, L., Ko, I., Koh, J., \& Kim, K. (2008). The influence of on-line brand community characteristics on community commitment and brand loyalty. International Journal of Electronic Commerce, 12(3), 57-80. https://doi.org/10.2753/JEC1086-4415120304

Kabadayi, S., \& Price, K. (2014). Consumer - Brand engagement on Facebook: Liking and commenting behaviors. Journal of Research in Interactive Marketing, 8(3), 203-223. https://doi.org/10.1108/JRIM-12-2013-0081

Kohli, C., Suri, R., \& Kapoor, A. (2015). Will social media kill branding? Business Horizons, 58(1), 35-44. https://doi.org/10.1016/j.bushor.2014.08.004

Lee, D., Kim, H. S., \& Kim, J. K. (2011). The impact of online brand community type on consumer's community engagement behaviors: Consumer-created vs. marketer-created online brand community in online social-networking web sites. Cyberpsychology, Behavior, and Social Networking, 14(1-2), 59-63. https://doi. org/10.1089/cyber.2009.0397

Leong, P. (2011). Role of social presence and cognitive absorption in online learning environments. Distance Education, 32(1), 5-28. https://doi.org/10.1080/01587919.2011.565495

Lin, C. A., \& Kim, T. (2016). Predicting user response to sponsored advertising on social media via the technology acceptance model. Computers in Human Behavior, 64, 710-718. https://doi.org/10.1016/j.chb.2016.07.027 
Lin, H. F. (2007). The impact of website quality dimensions on customer satisfaction in the B2C E-commerce context. Total Quality Management \& Business Excellence, 18(4), 363-378. https://doi.org/10.1080/14783360701231302

Lin, H. F. (2009). Examination of cognitive absorption influencing the intention to use a virtual community. Behaviour \& Information Technology, 28(5), 421-431. https://doi.org/10.1080/01449290701662169

McLean, G. (2018). Examining the determinants and outcomes of mobile app engagement - A longitudinal perspective. Computers in Human Behavior, 84, 392-403. https://doi.org/10.1016/j.chb.2018.03.015

Mishra, A. S. (2019). Antecedents of consumers' engagement with brand-related content on social media. Marketing Intelligence \& Planning, 37(4), 386-400. https://doi.org/10.1108/MIP-04-2018-0130

Mollen, A., \& Wilson, H. (2010). Engagement, telepresence and interactivity in online consumer experience: Reconciling scholastic and managerial perspectives. Journal of Business Research, 63(9-10), 919-925. https:// doi.org/10.1016/j.jbusres.2009.05.014

Nikolinakou, A., \& Phua, J. (2020). "Do human values matter for promoting brands on social media? How social media users" values influence valuable brand-related activities such as sharing, content creation, and reviews. Journal of Consumer Behaviour, 19(1), 13-23. https://doi.org/10.1002/cb.1790

Osei-Frimpong, K. (2019). Understanding consumer motivations in online social brand engagement participation. International Journal of Retail \& Distribution Management, 47(5), 511-529. https://doi.org/10.1108/ IJRDM-08-2018-0151

Passer, M. W., \& Smith, R. E. (2009). Psychology: The Science of Mind and Behaviour (4th ed.). McGraw-Hill.

Pletikosa Cvijikj, I., \& Michahelles, F. (2013). Online engagement factors on Facebook brand pages. Social Network Analysis and Mining, 3(4), 843-861. https://doi.org/10.1007/s13278-013-0098-8

Podsakoff, P. M., MacKenzie, S. B., Lee, J.-Y., \& Podsakoff, N. P. (2003). Common method biases in behavioral research: A critical review of the literature and recommended remedies. The Journal of Applied Psychology, 88(5), 879-903. https://doi.org/10.1037/0021-9010.88.5.879

Rauniar, R., Rawski, G., Yang, J., \& Johnson, B. (2014). Technology acceptance model (TAM) and social media usage: An empirical study on Facebook. Journal of Enterprise Information Management, 27(1), 6-30. https:// doi.org/10.1108/JEIM-04-2012-0011

Reychav, I., \& Wu, D. (2015). Are your users actively involved? A cognitive absorption perspective in mobile training. Computers in Human Behavior, 44, 335-346. https://doi.org/10.1016/j.chb.2014.09.021

Saadé, R., \& Bahli, B. (2005). The impact of cognitive absorption on perceived usefulness and perceived ease of use in on-line learning: An extension of the technology acceptance model. Information \& Management, 42(2), 317-327. https://doi.org/10.1016/j.im.2003.12.013

Sabermajidi, N., Valaei, N., Balaji, M. S., \& Goh, S. K. (2019). Measuring brand-related content in social media: a socialization theory perspective. Information Technology and People. 10.1108/ITP-10-2018-0497

Sanders, W. S., Wang, Y. J., \& Zheng, Q. (2019). Brand's Social Media Presence as Networks: The Role of Interactivity and Network Centrality on Engagement. Communication Research Reports, 36(2), 179-189. https:// doi.org/10.1080/08824096.2019.1590192

Schivinski, B. (2019a). Eliciting brand-related social media engagement: A conditional inference tree framework. Journal of Business Research. 10.1016/j.jbusres.2019.08.045

Schivinski, B. (2019b). Eliciting brand-related social media engagement: A conditional inference tree framework. Journal of Business Research. 10.1016/j.jbusres.2019.08.045

Schivinski, B., Christodoulides, G., \& Dabrowski, D. (2016). Measuring consumers' engagement with brandrelated social-media content: Development and validation of a scale that identifies levels of social-media engagement with brands. Journal of Advertising Research, 56(1), 64-80. https://doi.org/10.2501/JAR-2016-004

Schivinski, B., Muntinga, D. G., Pontes, H. M., \& Lukasik, P. (2019a). Influencing COBRAs: the effects of brand equity on the consumer's propensity to engage with brand-related content on social media. Journal of Strategic Marketing. 10.1080/0965254X.2019.1572641 
Schivinski, B., Muntinga, D. G., Pontes, H. M., \& Lukasik, P. (2019b). Influencing COBRAs: the effects of brand equity on the consumer's propensity to engage with brand-related content on social media. Journal of Strategic Marketing. 10.1080/0965254X.2019.1572641

Shao, G. (2009). Understanding the appeal of user-generated media: A uses and gratification perspective.). . Internet Research, 19(1), 7-25. doi:10.1108/10662240910927795

Sharman, R., Raghu, T. S., Rao, H. R., Kim, D. J., \& Zhang, D. (2009). The Effects of Sense of Presence, Sense of Belonging, and Cognitive Absorption on Satisfaction and User Loyalty toward an Immersive 3D Virtual World. In LNBIP (Vol. 52). www.secondlife.com

Simon, F., \& Tossan, V. (2018). Does brand-consumer social sharing matter? A relational framework of customer engagement to brand-hosted social media. Journal of Business Research, 85, 175-184. https://doi.org/10.1016/j. jbusres.2017.12.050

Smith, K. (2019). Brandwatch. https://www.brandwatch.com/blog/amazing-social-media-statistics-andfacts/\#section-10

Statista Research Department. (2020, February 19). Revenue of Samsung Electronics 2011-2019, by quarter. Statista.Com. https://www.statista.com/statistics/298704/samsung-quarterly-revenue/

Tabachnick, B. G., Fidell, L. S., \& Ullman, J. B. (2007). Using Multivariate Statistics (Vol. 5). Pearson.

Tam, C., \& Oliveira, T. (2016). Understanding the impact of m-banking on individual performance: DeLone \&amp; McLean and TTF perspective. Computers in Human Behavior, 61, 233-244. https://doi.org/10.1016/j. chb.2016.03.016

Tam, C., \& Oliveira, T. (2017). Understanding mobile banking individual performance: The DeLone \& McLean model and the moderating effects of individual culture. Internet Research, 27(3), 538-562. https://doi.org/10.1108/ IntR-05-2016-0117

van Doorn, J., Lemon, K. N., Mittal, V., Nass, S., Pick, D., Pirner, P., \& Verhoef, P. C. (2010). Customer engagement behavior: Theoretical foundations and research directions. Journal of Service Research, 13(3), 253-266. https://doi.org/10.1177/1094670510375599

VanMeter, R., Syrdal, H. A., Powell-Mantel, S., Grisaffe, D. B., \& Nesson, E. T. (2018). Don't Just “Like” Me, Promote Me: How Attachment and Attitude Influence Brand Related Behaviors on Social Media. Journal of Interactive Marketing, 43, 83-97. https://doi.org/10.1016/j.intmar.2018.03.003

Veloutsou, C., \& Guzman, F. (2017). The evolution of brand management thinking over the last 25 years as recorded in the Journal of Product and Brand Management. Journal of Product and Brand Management, 26(1), 2-12. https://doi.org/10.1108/JPBM-01-2017-1398

Voorveld, H. A. M., van Noort, G., Muntinga, D. G., \& Bronner, F. (2018). Engagement with Social Media and Social Media Advertising: The Differentiating Role of Platform Type. Journal of Advertising, 47(1), 38-54. https://doi.org/10.1080/00913367.2017.1405754

Yang, Y., Asaad, Y., \& Dwivedi, Y. (2017). Examining the impact of gamification on intention of engagement and brand attitude in the marketing context. Computers in Human Behavior, 73, 459-469. https://doi.org/10.1016/j. chb.2017.03.066

Zaglia, M. E. (2013). Brand communities embedded in social networks. Journal of Business Research, 66(2), 216-223. https://doi.org/10.1016/j.jbusres.2012.07.015

Zheng, Y., Zhao, K., \& Stylianou, A. (2013). The impacts of information quality and system quality on users' continuance intention in information-exchange virtual communities: An empirical investigation. Decision Support Systems, 56, 513-524. https://doi.org/10.1016/j.dss.2012.11.008 


\section{APPENDIX A}

Figure 2.

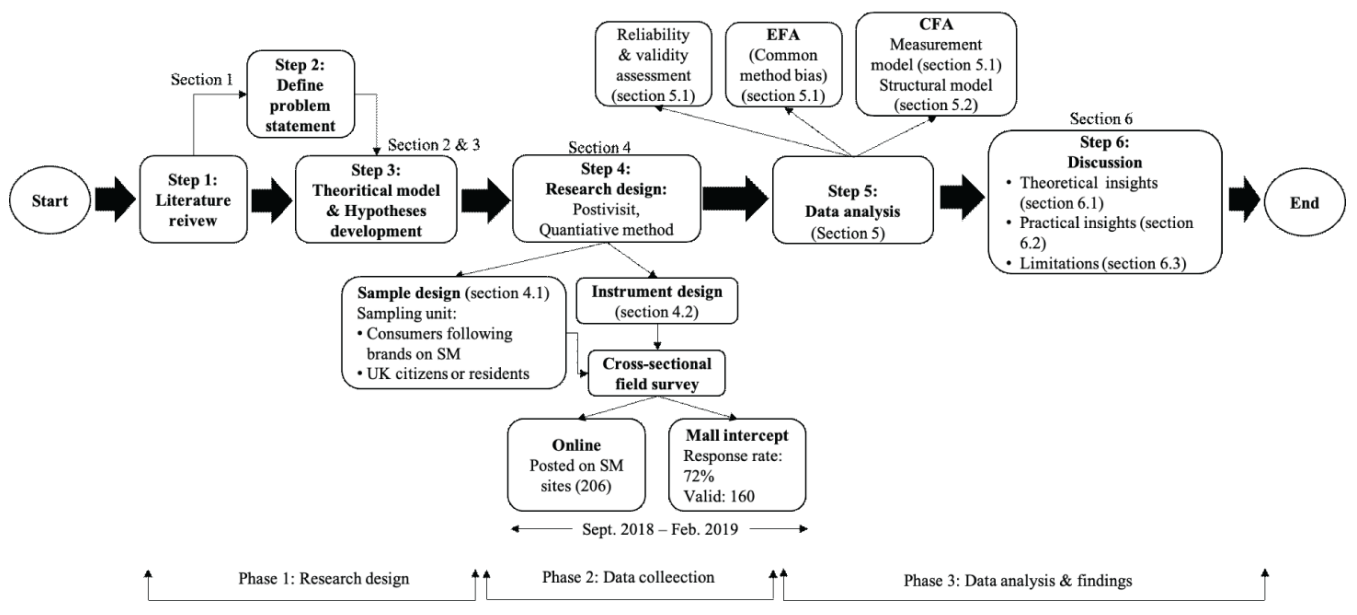




\section{APPENDIX B}

Table 6. The rotated component matrix

\begin{tabular}{|c|c|c|c|c|c|c|c|c|c|c|}
\hline & & $\begin{array}{c}\text { Factor } \\
1\end{array}$ & $\begin{array}{c}\text { Factor } \\
2\end{array}$ & $\begin{array}{c}\text { Factor } \\
3\end{array}$ & $\begin{array}{c}\text { Factor } \\
4\end{array}$ & $\begin{array}{c}\text { Factor } \\
5\end{array}$ & $\begin{array}{c}\text { Factor } \\
6\end{array}$ & $\begin{array}{c}\text { Factor } \\
7\end{array}$ & $\begin{array}{c}\text { Factor } \\
8\end{array}$ & $\begin{array}{c}\text { Factor } \\
9\end{array}$ \\
\hline o & $\begin{array}{l}\text { SYSQ1 } \\
\text { SYSQ2 } \\
\text { SYSQ3 } \\
\text { SYSQ4 } \\
\text { SYSQ5 }\end{array}$ & $\begin{array}{l}0.773 \\
0.774 \\
0.746 \\
0.771 \\
0.744\end{array}$ & & & & & & & & \\
\hline $\begin{array}{l}\text { O } \\
\text { 号 } \\
\text { Z }\end{array}$ & $\begin{array}{l}\text { INFQ1 } \\
\text { INFQ2 } \\
\text { INFQ3 } \\
\text { INFQ4 } \\
\text { INFQ5 }\end{array}$ & & $\begin{array}{l}0.771 \\
0.798 \\
0.747 \\
0803 \\
0.731\end{array}$ & & & & & & & \\
\hline 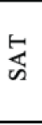 & $\begin{array}{l}\text { SAT1 } \\
\text { SAT2 } \\
\text { SAT3 } \\
\text { SAT4 }\end{array}$ & & & $\begin{array}{l}0.778 \\
0.815 \\
0.811 \\
0.787 \\
\end{array}$ & & & & & & \\
\hline $\overrightarrow{\mid m}$ & $\begin{array}{l}\mathrm{BI} 1 \\
\mathrm{BI} 2 \\
\mathrm{BI} 3 \\
\mathrm{BI} 4\end{array}$ & & & & $\begin{array}{l}0.896 \\
0.852 \\
0.821 \\
0.854\end{array}$ & & & & & \\
\hline $\begin{array}{l}8 \\
\text { 要 }\end{array}$ & $\begin{array}{l}\text { PEOU1 } \\
\text { PEOU2 } \\
\text { PEOU3 } \\
\text { PEOU4 }\end{array}$ & & & & & $\begin{array}{l}0.772 \\
0.843 \\
0.844 \\
0.749\end{array}$ & & & & \\
\hline D & $\begin{array}{l}\text { PU1 } \\
\text { PU2 } \\
\text { PU3 } \\
\text { PU4 }\end{array}$ & & & & & & $\begin{array}{l}0.863 \\
0.860 \\
0.861 \\
0.866\end{array}$ & & & \\
\hline 四 & $\begin{array}{l}\text { HE1 } \\
\text { HE2 } \\
\text { HE3 }\end{array}$ & & & & & & & $\begin{array}{l}0.815 \\
0.843 \\
0.812\end{array}$ & & \\
\hline 届 & $\begin{array}{l}\text { FI1 } \\
\text { FI2 } \\
\text { FI3 }\end{array}$ & & & & & & & & $\begin{array}{l}0.909 \\
0.894 \\
0.893\end{array}$ & \\
\hline$\theta$ & $\begin{array}{l}\text { TD1 } \\
\text { TD2 } \\
\text { TD3 } \\
\text { TD4 }\end{array}$ & & & & & & & & & $\begin{array}{l}0.895 \\
0.895 \\
0.892 \\
0.899\end{array}$ \\
\hline
\end{tabular}




\section{APPENDIX C}

Table 7. Rotated component of CESBC

\begin{tabular}{|c|c|c|c|c|}
\hline & & Factor 1 & Factor 2 & Factor 3 \\
\hline फ्ट & $\begin{array}{l}\text { CSP1 } \\
\text { CSP2 } \\
\text { CSP3 }\end{array}$ & $\begin{array}{l}0.905 \\
0.833 \\
0.940\end{array}$ & & \\
\hline 点 & $\begin{array}{l}\text { CONT1 } \\
\text { CONT2 } \\
\text { CONT3 } \\
\text { CONT4 }\end{array}$ & & $\begin{array}{l}0.822 \\
0.896 \\
0.906 \\
0.890\end{array}$ & \\
\hline 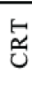 & $\begin{array}{l}\text { CRT1 } \\
\text { CRT2 } \\
\text { CRT3 }\end{array}$ & & & $\begin{array}{l}0.878 \\
0.894 \\
0.888\end{array}$ \\
\hline
\end{tabular}

Reham Shawky Ebrahim received her PhD in Business Management from Brunel University London in 2013. She joined Faculty of Commerce, Tanta University, Egypt as a lecturer in Marketing in November, 2013. She holds a Master degree in personnel management from Faculty of Commerce, Tanta University. In 2018, Dr Reham secured a six months postdoctoral research fellow at Faulty of Management and Law, University of Bradford. Her research interests focus on consumer brand engagement, brand experience, social media marketing and consumer behaviour. She has published articles in international journals such as Journal of Marketing Management and Journal of Relationship Marketing and in journals. She participated and presented her research in various international conferences including 14th Global Brand Conference and British Academy of Management. 